\title{
PRZETWARZANIE DANYCH OSOBOWYCH DOTYCZĄCYCH ZATRUDNIENIA W KOŚCIOŁACH I INNYCH ZWIĄZKACH WYZNANIOWYCH
}

\begin{abstract}
Processing of personal data on employment in churches and religious associations

In this work authors analyze existing legal regulations in the state and internal (canonical) legal order, concernig processing of personal data on employments in churches and religious associotions. Presented considerations regarding the principles of employment in churches and other religious associatons indicated that from formal side there are no significant differences with respect to other entities appearing in the legal turnover. The right to autonomy allows churches and religious associations in the borders of state law, to determine the rules processing of personal data, in accordance with the assumptions resulting from their specificity.
\end{abstract}

Słowa kluczowe: dane osobowe, Kościoły i związki wyznaniowe

Key words: personal data, churches and religious associations

\section{Wprowadzenie}

W Kościołach i innych związkach wyznaniowych zatrudnianie osób na umowę o pracę i w pozostałych formach tzw. elastycznych służy nie tylko realizacji celów statutowych, ale może dotyczyć prowadzenia przez te podmioty innej działalności, np. edukacyjnej czy gospodarczej. W obu tych płaszczyznach dochodzi do przetwarzania danych osobowych, m.in. w ramach prowadzonej dokumentacji dotyczącej zatrudnienia. Podlegają ona jednak odrębnym od rozwiązań państwowych, wewnętrznym regulacjom, gdy przed 25 maja 2018 r. zostały dostosowane do RODO, a wyznaniowe (kościelne) osoby prawne prowadzą działalność zgodnie z przyjętą misją religijną i celami statutowymi, w ramach konstrukcji prawnej Kościoły i inne związki wyznaniowe. Celem artykułu jest przedstawienie podstaw prawnych tworzenia przez Kościoły i inne związki wyznaniowe tych własnych regulacji dotyczących przetwarzania danych osobowych i odnoszących się także do zatrudnienia. 


\section{Podstawy prawne autonomii Kościołów i innych związków wyznaniowych w obrocie danymi osobowymi}

We współczesnych państwach wzajemne relacje między państwem a Kościołem i innym związkiem wyznaniowym regulują przepisy ustrojowe. Sprowadzają się one do określonego modelu ${ }^{1}$. W rzeczywistości polskiej relacje państwa do Kościołów i innych związków wyznaniowych zostały oparte na zasadach autonomii i niezależności, które gwarantuje ustawa zasadnicza w art. $25 \$ 3^{2}$ oraz art. 1 konkordatu między Rzecząpospolitą Polską a Stolicą Apostolską ${ }^{3}$. Wyraża je także 15 szczegółowych ustaw o stosunku państwa do poszczególnych Kościołów i innych związków wyznaniowych ${ }^{4}$. Niezależność przy wykonywaniu swoich funkcji religijnych zapewnia im też ustawa o gwarancjach wolności sumienia i wyznania 5 .

Gwarancje te wpisują się w zapewnione w Traktacie o Unii Europejskiej prawa człowieka i podstawowe wolności, w tym także wolność myśli, sumienia i religii oraz tożsamość narodową państw członkowskich ${ }^{6}$. Z kolei dołączona do Traktatu Amsterdamskiego tzw. klauzula kościelna (klauzula o kościołach) ${ }^{7}$ stała się na mocy Traktatu o funkcjonowaniu Unii Europejskiej obowiązującą normą prawną. Potwierdza ona, że Unia Europejska przestrzega i nie narusza statusu Kościołów i innych związków wyznaniowych w krajowych porządkach prawnych. Z punktu widzenia prawa unijnego (art. 17 Traktatu o funkcjonowaniu UE) Unia Europejska nie ma kompetencji, aby wpływać na status prawny Kościołów i innych związków wyznaniowych w państwach członkowskich, natomiast powinna prowadzić z nimi dialog ${ }^{8}$.

Konsekwencją stosunku Unii Europejskiej do religii i Kościołów oraz innych związków wyznaniowych jest art. 91 Rozporządzenia Parlamentu Europejskiego i Rady (UE) 2016/679 z dnia 27 kwietnia 2016 r. w sprawie ochrony osób fizycznych w związku z przetwarzaniem danych osobowych i w sprawie swobodnego przepływu takich danych oraz uchylenia Dyrektywy 95/46/WE (ogólne rozporządzenie o ochronie danych) ${ }^{9}$, które ma zastosowanie od dnia 25 maja 2018 r. (czytaj: RODO). Stanowi on, że jeżeli w państwie członkowskim w momencie wejścia niniejszego rozporządzenia w życie Kościoły i związki lub wspólnoty wyznaniowe stosują szczegółowe zasady ochrony osób fizycznych w związku z przetwarzaniem danych osobowych, zasady takie mogą być nadal

1 K. Orzeszyna, Podstawy relacji między państwem a Kościołami w konstytucjach państw członkowskich i traktatach Unii Europejskiej, Lublin 2007, passim.

2 Dz. U. 1997, Nr 78, poz. 483 ze zm.

3 Dz. U. z 1998 r., Nr 51, poz. 318.

4 Zob. m.in. P. Wolnicki, O. Kucharski, Formy zatrudnienia i ich dokumentacja w kościołach i innych związkach wyznaniowych, Częstochowa 2018, s. 34-35.

5 Tekst jednolity Dz. U. z 2017 r., poz. 1153.

6 Traktat z Maastricht Dz. Urz. UE C 191/1992, s. 1.

7 Dz. Urz. UE C 340/1997, s. 133 - zob. Deklaracja Nr 11 i s. 35 pr. wyzn.

8 Wersja skonsolidowana: Dz. Urz. UE C 83/2010, s. 47.

9 Dz. Urz. UE L. 119/1, z 4.05.2016 r., EUR Lex. 
stosowane, pod warunkiem że zostaną dostosowane do tegoż rozporządzenia. Ponadto Kościoły i związki wyznaniowe, które stosują te szczegółowe zasady, podlegają nadzorowi niezależnego organu nadzorczego, który może być organem odrębnym, z zastrzeżeniem że spełnia warunki określone w rozdziale VI RODO.

Podjęte przez Kościoły i inne związki wyznaniowe o uregulowanej sytuacji prawnej ${ }_{\mathrm{w}} \mathrm{RP}^{10}$ działania na rzecz dostosowania regulacji wewnętrznych do RODO spowodowały obowiązywanie w wewnętrznym (kanonicznym) porządku prawnym własnych regulacji w odniesieniu do m.in.:

- Kościoła katolickiego w Rzeczypospolitej Polskiej - Dekretu ogólnego w sprawie ochrony osób fizycznych w związku z przetwarzaniem danych osobowych w Kościele katolickim wydany przez Konferencję Episkopatu Polski w dniu 13 marca 2018 r., podczas 378. Zebrania Plenarnego w Warszawie, na podstawie kan. 455 Kodeksu prawa kanonicznego, w związku z art. 18 Statutu Konferencji Episkopatu Polski, po uzyskaniu specjalnego zezwolenia Stolicy Apostolskiej z dnia 3 czerwca 2017 r. ${ }^{11}$;

- Kościoła Zielonoświątkowego w Rzeczypospolitej Polskiej - Regulamin Kościoła Zielonoświątkowego dotyczący ochrony danych osobowych z dnia 18 kwietnia 2018 r. $^{12}$;

- Kościoła Ewangelicko-Augsburskiego w Rzeczypospolitej Polskiej - Regulamin Ochrony Danych Osobowych Kościoła Ewangelicko-Augsburskiego w Rzeczypospolitej Polskiej z dnia 23 kwietnia 2018 r. przyjęty Uchwałą Rady Synodalnej $\mathrm{nr} \mathrm{RS} / \mathrm{XIV} / 12 / 1 / 2018^{13}$;

- Kościoła Ewangelicko-Reformowanego w Rzeczypospolitej Polskiej- Regulaminu Ochrony Danych Osobowych Kościoła Ewangelicko-Reformowanego w Rzeczypospolitej Polskiej z dnia 12 maja $2018 \mathrm{r}^{14}$.

Wprowadzone przez te podmioty konfesyjne własne przepisy proceduralne w zakresie ochrony danych osobowych wyłączają kognicję organów państwa oraz prawa państwowego i unijnego ${ }^{15}$. Regulacje te, mając charakter generalnej procedury ochrony i zabezpieczenia

10 Uregulowaną sytuację prawną w polskim porządku prawnym mają te Kościoły i inne związki wyznaniowe, które mają ją uregulowaną na drodze szczegółowych ustaw lub zostały wpisane do rejestru Kościołów i związków wyznaniowych prowadzonego przez ministra właściwego do spraw wyznań. Por. E. Kulesza, Ochrona danych osobowych a wolność sumienia $i$ wyznania w prawodawstwie polskim, w: P. Majer (red.), Ochrona danych osobowych i prawo do prywatności w Kościele, Kraków 2001, s. 14; OTK 1998/3/32; Wyrok NSA z 21 kwietnia 2015 r., I OSK 1968/13, http://orzeczenia.nsa.gov.pl/doc1CB5103597 (dostęp: 14.07.2018).

11 „Akta Konferencji Episkopatu Polski” 2018, nr 30 (dalej: Dekret).

$12 \mathrm{http}: / / \mathrm{kz} . \mathrm{pl} / \mathrm{kzw} / \mathrm{wp}-$ content/uploads/2018/05/1.-Regulaminu-Zwia\%CC\%A8zku-Wyznaniowego-dotycza\%CC\%A8cego-Ochrony-Danych-sent.pdf (dalej: RKZ).

13 https://bik.luteranie.pl/pl/strona_glowna/rodo.htm (dalej: RKEA).

$14 \mathrm{http} / /$ reformowani.pl/images/kosciol/Regulamin-Ochrony-Danych-Osobowych-KER.pdf (dalej: RKER).

15 Wyrok WSA w Warszawie z 28 sierpnia 2013 r., II SA/Wa1229/13, http:// orzeczenia nsa.gov. pl/doc/EA288AC47F (dostęp: 10.07.2018); A. Mezglewski, Perspektywa i zakres implementacji nowych przepisów Unii Europejskiej dotyczących przetwarzania danych osobowych przez związki wyznaniowe, w: S. Dziekoński, P. Drobek, Ochrona danych osobowych w Kościele, Warszawa 2016, s. 40-41, 45-46; 
przetwarzania danych osobowych, mogą zatem być stosowane do przetwarzania danych osobowych w zatrudnieniu. Definiują podstawowe pojęcia, zasady przetwarzania danych osobowych, prawa osób, których dane są przetwarzane, procedurę zarządzania ochroną danych, sprawy nadzoru i rozpatrywania skarg. Nie określają jednak zakresu przetwarzanych danych osobowych, także tych stanowiących kategorię szczególnych (wrażliwych) danych osobowych, które dotyczą przekonań religijnych, co jest niezbędne do realizacji funkcji i praw zawartych w prawie wewnętrznym (kanonicznym) tych związków wyznaniowych ${ }^{16}$.

\section{Zasady i dopuszczalność przetwarzania danych osobowych}

W polskim porządku prawnym ochrona danych osobowych ma swoje podstawy w art. 47 i art. 51 ust. 1 Konstytucji RP i dotyczy każdej osoby. Przepisy ustawy zasadniczej tworzą zatem ogólne ramy prawne dla przetwarzania danych osobowych w relacjach podmiotowych także między zatrudniającym i zatrudnianym ${ }^{17}$. Ponadto problematyka dotycząca ochrony danych osobowych, jak to już zostało zaznaczone, wynika także z prawa UE, przede wszystkim z RODO.

W tym miejscu należy wspomnieć, że ochrona danych osobowych wykorzystywanych do celów zatrudnienia miała miejsce w rekomendacji nr R(89)2 Komitetu Ministrów Rady Europy z 18 stycznia 1989 r. $^{18}$ Następnie zagadnienie ochrony danych osobowych pracowników (osób, które są lub były zatrudnione oraz poszukują pracy) zostało podjęte jeszcze w ostatniej dekadzie ubiegłego wieku przez Międzynarodowe Biuro Pracy. Zawarte w pkt 3.1 wytycznych, także niemających statusu źródła prawa, pojęcie dane osobowe pracowników odnosiło się do każdej informacji dotyczącej pracownika o ustalonej lub możliwej do ustalenia tożsamości ${ }^{19}$. Na gruncie prawa Unii Europejskiej źródłem prawa wymagającym implementacji w krajowym porządku prawnym, a odnoszącym się do ogólnych gwarancji ochrony danych osobowych była Dyrektywa 95/46WE z 24 października 1995 r. w sprawie ochrony osób fizycznych w zakresie przetwarzania danych osobowych i swobodnego przepływu tych danych. $Z$ dniem jej uchylenia i wprowadzenia w życie od dnia 25 maja 2018 r. RODO jego przepisy wiążą w całości i wymagają bezpośredniego stosowania.

Z przepisami RODO korespondują gwarantujące ochronę danych osobowych regulacje Kodeksu pracy (kp). Kwestię pozyskiwania i udostępniania ich przez pracodawcę w odniesieniu do kandydatów do pracy oraz pracowników reguluje art. $22^{1} \mathrm{kp}$. Na

M. Poniatowski, Przetwarzanie danych osobowych $w$ kościelnych organizacjach pożytku publicznego, w: S. Dziekoński, P. Drobek, Ochrona danych osobowych w Kościele, Warszawa 2016, s. 176-178.

$16 \$ 1$ p. 2 RKZ; Art. 7 ust. 2 Dekretu.

17 Por. Kodeks pracy. Komentarz. Wyd. 2, A. Sobczyk (red.), Warszawa 2015, s. 100.

18 www.giodo.gov. Pl.

19 D. Makowski, Ochrona danych osobowych wedlug wytycznych Międzynarodowego Biura Pracy, „Inspektor Pracy” 2000, 1-2, s. 23. 
podstawie jego $\$ 4$, dodatkowo zakres przedmiotowy danych wymaganych od kandydata do pracy może wynikać także bezpośrednio lub pośrednio z przepisów rangi ustawowej w odniesieniu np. do określonych grup zawodowych ${ }^{20}$. W sprawach nieuregulowanych w tym przepisie ustawodawca odsyła do ustawy o ochronie danych osobowych (art. $22^{1}$ $\$ 5 \mathrm{kp}$ ). W odniesieniu do danych ujawniających religię, wyznanie lub światopogląd, które co do zasady nie powinny być przetwarzane, czyni wyjątek $\mathrm{w}$ art. $18^{3 \mathrm{~b}} \$ 4 \mathrm{kp}^{21}$. Zgodnie $\mathrm{z}$ jego tenorem możliwe jest, $\mathrm{w}$ odniesieniu do zatrudnionych, przetwarzanie danych osobowych dotyczących przekonań religijnych przez Kościoły i inne związki wyznaniowe, a także organizacje, których etyka opiera się na religii, wyznaniu lub światopoglądzie ${ }^{22}$. Kierowanie się tymi przesłankami w procesie dostępu do zatrudnienia na podstawie art. $18^{3 \mathrm{~b}} \$ 2$ wymaga wskazania rzeczywistego i decydującego wymagania zawodowego stawianego pracownikom, proporcjonalnego do osiągnięcia zgodnego z prawem celu zróżnicowania sytuacji osoby zatrudnianej.

Kwestie ochrony danych osobowych odnoszących się do przekonań religijnych i przynależności wyznaniowej regulowała wreszcie w polskim porządku prawnym wielokrotnie nowelizowana Ustawa o ochronie danych osobowych z dnia 29 sierpnia 1997 r., która została uchylona z dniem 25 maja 2018 r. ${ }^{23}$ Jej art. 27 ust. 2 pkt 4 stanowił, że przetwarzanie tego typu danych jest dopuszczalne, gdy jest to niezbędne do wykonania statutowych zadań Kościołów i innych związków wyznaniowych i pod warunkiem, że przetwarzanie danych dotyczy wyłącznie członków tych organizacji lub instytucji albo osób utrzymujących z nimi stałe kontakty (bądź wyrażających taką wolę), w związku $\mathrm{z}$ ich działalnością i zapewnione są pełne gwarancje ochrony przetwarzanych danych.

Po wejściu w życie przepisów RODO obowiązująca Ustawa z dnia 10 maja $2018 \mathrm{r}$. o ochronie danych osobowych ${ }^{24} \mathrm{w}$ art. 107 zabrania przetwarzania danych dotyczących przekonań religijnych lub światopoglądowych z wyjątkiem podmiotów do tego uprawnionych. Przepis ten należy interpretować zgodnie z regulacjami zawartymi w RODO. Jako uprawnione w myśl tego rozporządzenia do przetwarzania tych danych są według art. 9 ust. $2 \mathrm{~d}$ te podmioty o celach religijnych, które przetwarzają takie dane wyłącznie swoich członków lub byłych członków tego podmiotu lub osób utrzymujących z nim stałe kontakty w związku z jego celami oraz że dane osobowe nie są ujawniane poza tym podmiotem bez zgody osób, których dane dotyczą. W literaturze przedmiotu do osób utrzymujących stałe kontakty z Kościołami i innymi związkami wyznaniowymi w związku z ich celami statutowymi zalicza się osoby zatrudnione ${ }^{25}$. Niemniej pojęcie „osób utrzymujących stałe kontakty” z Kościołami i innymi związkami wyznaniowymi

20 Kodeks pracy..., s. 102.

21 P. Wolnicki, O. Kucharski, Formy zatrudnienia..., s. 148-151.

22 M.A. Mielczarek, Realizacja wolności religijnej w zatrudnieniu pracowniczym, Warszawa 2013, s. 124.

23 Tekst jednolity Dz. U. z 2016 r., poz. 922 ze zm.

24 Dz. U. 2018, poz. 1000.

25 A. Drozd, Ustawa o ochronie danych osobowych. Komentarz. Wzory pism i przepisy, Warszawa 2006, s. 174-178; A. Mezglewski, Działalność związów wyznaniowych, a ochrona danych osobowych, Studia z Prawa Wyznaniowego 2007, 10, s. 152; P. Sobczyk, Ograniczenie praw podmiotu ze względu na 
domaga się doprecyzowania na gruncie różnych systemów prawa (unijnego, państwowego i wewnętrznego, a więc także kanonicznego ${ }^{26}$.

W obecnym stanie prawnym te Kościoły, które dostosowały swoje regulacje związane z przetwarzaniem ${ }^{27}$ danych osobowych ${ }^{28}$ do RODO i wprowadziły własne rozwiązania, nie tylko „w ramach swoich uprawnień mają prawo do gromadzenia oraz przetwarzania danych członków Kościoła, jego sympatyków oraz pracowników zatrudnianych w jego organizacjach i instytucjach" ${ }^{29}$, co zapewnia wszystkim Kościołom i innym związkom wyznaniowym o uregulowanej sytuacji prawnej art. 9 ust. $2 \mathrm{~d}$ tegoż rozporządzenia, ale też opierają się na przyjętych autonomicznie procedurach wewnętrznych i nie podlegają nadzorowi państwowych organów ochrony danych osobowych, które (na podstawie p. 127 RODO) są właściwe w sprawach dotyczących zatrudnienia. Wprowadzone w nich regulacje opierają się na ogólnych zasadach dotyczących przetwarzania danych osobowych w rozumieniu przepisów RODO: zgodności z prawem, rzetelności i przejrzystości, celowości, minimalizacji danych (adekwatności), prawidłowości, ograniczenia przechowywania, integralności i poufności oraz rozliczalności. W odniesieniu do zatrudnionych może to mieć miejsce, gdy jest spełniony przynajmniej jeden z warunków:

1) dotyczy osoby utrzymującej stałe kontakty z Kościołem w związku z jego celami statutowymi;

2) jest niezbędne do wykonania umowy, której stroną jest osoba, której dane dotyczą lub do podjęcia działań na żądanie osoby, której dane dotyczą, przed zawarciem umowy;

3) przetwarzanie jest niezbędne do wypełnienia obowiązku prawnego ciążącego na administratorze;

przetwarzanie danych osobowych dotyczących przekonań religijnych i przynależności wyznaniowej, Studia z Prawa Wyznaniowego 2010, 13, s. 152.

26 P. Mazurkiewicz, Ochrona danych osobowych $w$ Kościołach $i$ związkach wyznaniowych w świetle Rozporządzenia Parlamentu Europejskiego i Rady (UE) 2016/679 z dnia 27 kwietnia 2016 r. w sprawie ochrony osób fizycznych $w$ zwiazk $z$ z przetwarzaniem danych osobowych i w sprawie swobodnego przepływu takich danych oraz uchyleniu dyrektywy 95/46 WE, w: S. Dziekoński, P. Drobek, Ochrona danych osobowych w Kościele, Warszawa 2016.

27 „Przetwarzanie” oznacza operację lub zestaw operacji wykonywanych na danych osobowych lub zestawach danych osobowych w sposób zautomatyzowany lub niezautomatyzowany, taką jak zbieranie, utrwalanie, organizowanie, porządkowanie, przechowywanie, adaptowanie lub modyfikowanie, pobieranie, przeglądanie, wykorzystywanie, ujawnianie poprzez przesłanie, rozpowszechnianie lub innego rodzaju udostępnianie, dopasowywanie lub łączenie, ograniczanie, usuwanie lub niszczenie" - art. 4 p. 2 RODO.

28 „Dane osobowe” oznaczają informacje o zidentyfikowanej lub możliwej do zidentyfikowania osobie fizycznej („osobie, której dane dotyczą”); możliwa do zidentyfikowania osoba fizyczna to osoba, którą można bezpośrednio lub pośrednio zidentyfikować, w szczególności na podstawie identyfikatora, takiego jak imię i nazwisko, numer identyfikacyjny, dane o lokalizacji, identyfikator internetowy lub jeden bądź kilka szczególnych czynników określających fizyczną, fizjologiczną, genetyczną, psychiczną, ekonomiczną, kulturową lub społeczną tożsamość osoby fizycznej” - art. 4 p. 1 RODO.

29 Prawo Wewnętrzne Kościoła Ewangelicko-Metodystycznego w Rzeczypospolitej Polskiej, Roz. XI. Ochrona Danych Osobowych, art. 92 ust. 1. 
4) przetwarzanie jest niezbędne do celów wynikających z prawnie uzasadnionych interesów realizowanych przez administratora ${ }^{30}$.

Kościelne regulacje dotyczące przetwarzania danych osobowych odnoszą się do wszelkich operacji przetwarzania danych osobowych przez Kościół i jego osoby prawne, gdy realizują statutowe funkcje religijne ${ }^{31}$. Przy założeniu, że Kościół jako całość i jego osoby prawne oraz ich jednostki organizacyjne przestrzegają powszechnie obowiązujących przepisów prawa niesprzecznych z prawem kościelnym oraz jego doktryną, objętych konstytucyjnie gwarantowanymi autonomią i niezależnością Kościoła ${ }^{32}$.

Należy zatem wnioskować, że przetwarzanie danych osobowych w podmiotach konfesyjnych realizujących statutowe funkcje może się opierać na przesłankach, które mają zastosowanie także w przypadku zatrudnienia niezależnie od jego formy. Jak bowiem podkreśla WSA w Warszawie, nie można przyjąć, że normy prawa pracy zapewniają dalej idącą ochronę informacji o pracowniku, aniżeli ustawa o ochronie danych osobowych, gdyż to właśnie w świetle jej przepisów powinna być prowadzona kontrola prawidłowości przetwarzania innych danych niż wymienione w art. $22^{1} \$ 1-4 \mathrm{kp}^{33}$.

Zatem w przypadku zatrudnionych w formie umów o pracę podstawowym źródłem prawa umożliwiającym przetwarzanie danych osobowych, a przede wszystkim wskazującym zakres gromadzonych informacji będzie wskazany już art. $22^{1} \S 1-4 \mathrm{kp}$. W tym zakresie rola regulacji wewnętrznych Kościołów będzie niewielka, w zasadzie ograniczając się do doprecyzowania reguł stosowania uprawnień wynikających z art. $18^{3 \mathrm{~b}} \S 4 \mathrm{kp}$.

Odmienna będzie rola przepisów wewnętrznych w przypadku zatrudniania w innej formie niż umowa o pracę. W związku z brakiem szczegółowych regulacji (w porównaniu $\mathrm{z}$ umowami o pracę) dotyczących ochrony danych osobowych zleceniobiorcy, wykonawcy dzieła czy woluntariusza w tych przypadkach, poza zasadami wynikającymi z RODO, będą miały zastosowanie w pełnym zakresie przepisy wewnętrznych źródeł prawa danego Kościoła. W szczególności będzie to polegało na realizacji wynikającej z RODO ogólnej zasady prawa do gromadzenia danych niezbędnych do wykonania umowy, której stroną jest osoba, której dane dotyczą, lub do podjęcia działań na żądanie osoby, której dane dotyczą, przed zawarciem umowy.

Na podstawie powyższych rozważań przetwarzanie danych osobowych, oparte na wewnętrznym (kanonicznym) porządku prawnym, także w związku z zatrudnieniem w Kościołach i innych związkach wyznaniowych, jest uprawnione w stosunku do osób, które są członkami Kościoła lub nimi nie są, ale utrzymują z nimi stałe kontakty, niezbędne do wykonania statutowych zadań Kościołów i innych związków wyznaniowych,

$30 \$ 4$ RKER.

$31 \$ 1$ ust. 4 RKER; $\$ 1$ ust. 2 i 3 RKZ; art. 58a ust. 4 Uchwała Krajowej Konferencji Kościoła Chrześcijan Baptystów w RP z dnia 18 maja 2018 r. o zmianie uchwały Międzykonferencyjnego Zjazdu Delegatów Kościoła Chrześcijan Baptystów w Rzeczypospolitej Polskiej z dnia 1 października 2005 r. Zasadnicze Prawo Wewnętrzne Kościoła Chrześcijan Baptystów w Rzeczypospolitej Polskiej (Ochrona danych osobowych. Rejestry kościelne); $\$ 1$ ust. 3 RKER.

32 \$ 1 ust. 2 RKEA; $\$ 2$ ust. 1 RKZ; $\$ 1$ ust. 2 RKER.

33 Wyrok WSA w Warszawie z 27 listopada 2008 r., II SA/Wa 903/08, Legalis. 
w związku z ich działalnością, a więc są w nich zatrudnione na umowę o pracę lub inne umowy cywilnoprawne. Rodzi to bowiem pewne zobowiązania prawne ciążące na podmiocie zatrudniającym, m.in. związane z przetwarzaniem danych osobowych $\mathrm{w}$ ramach prowadzeniem dokumentacji osobowo-płacowej (akt osobowych, ewidencji czasu pracy oraz ewidencji wynagrodzeń, wydawania świadectwa pracy) dla umowy o pracę, a w przypadku nietypowych form zatrudnienia, choćby tylko dokumentacji i ewidencji ubezpieczeń społecznych i zdrowotnych, które każdy zatrudniający powinien posiadaćs ${ }^{34}$. Ma to zatem znaczenie dla ochrony prawnych interesów stron zatrudnienia. Musiał jednak zostać spełniony jeszcze jeden bardzo istotny warunek, a mianowicie należało zapewnić pełne gwarancje ochrony przetwarzanych danych. To, jak zaznaczono w prezentowanym artykule, spełniają szczegółowe regulacje wewnętrzne, które zostały dostosowane do RODO. W przypadku Kościoła katolickiego określają je także sformułowane w tym normatywie wyraźnie przywołane przepisy dotyczące przechowywania i zabezpieczania danych $w$ archiwach kościelnych ${ }^{35}$, obok wzorowanej na krajowym prawie archiwalnym ochronie prawnej przechowywania dokumentacji osobowej i płacowej ${ }^{36}$.

\section{Podsumowanie}

Obowiązki podmiotu zatrudniającego związane z ochroną danych osobowych dotyczących zatrudnienia są regulowane przez przepisy różnych gałęzi prawa. Zakres danych koniecznych pracodawcy do nawiązania stosunku pracy i podczas jego przebiegu reguluje art. $22^{1} \mathrm{kp} . \mathrm{Z}$ jego treści wynika zatem, jakich informacji pracodawca nie może żądać od zatrudnionych pracowników. Problematykę przetwarzania danych osobowych w innych formach niż umowa o pracę reguluje natomiast ustawa o ochronie danych osobowych. $\mathrm{Z}$ kolei warunki i środki techniczne związane $\mathrm{z}$ archiwizacją dokumentacji pracowniczej, przede wszystkim po okresie ustania zatrudnienia, określa ustawa o narodowym zasobie archiwalnym i archiwach. Powyższe regulacje w polskim porządku prawnym korespondują z przepisami RODO.

RODO potwierdziło też status prawny Kościołów i innych związków wyznaniowych w poszczególnych państwach, dając im możliwość stosowania własnych uregulowań w zakresie ochrony danych osobowych, o ile zostaną one dostosowane do jego unormowań. W polskim porządku prawnym $\mathrm{z}$ tego prawa mogły skorzystać te podmioty konfesyjne, które uregulowały swój status i funkcjonują w ramach konstrukcji prawnej Kościoły i inne związki wyznaniowe. Wprowadzone jedynie przez niektóre Kościoły i inne związki wyznaniowe regulacje i procedury wewnętrzne dostosowane do RODO zostały uszczegółowione, przy zachowaniu autonomii i niezależności, co jest przejawem różnorodności porządków prawnych w państwie demokratycznym

34 Por. P. Wolnicki, O. Kucharski, Formy zatrudnienia..., s. 193-219.

35 Art. 24 i 25 Dekretu.

36 P. Wolnicki, O. Kucharski, Formy zatrudnienia..., s. 223-230. 
oraz poszanowania wolności religijnej w wymiarze instytucjonalnym. Regulacja ta koresponduje w pełni $\mathrm{z}$ art. $22^{1}$ i art. $18^{3 \mathrm{~b}} \$ 4 \mathrm{kp}$ oraz art. 107 Ustawy $\mathrm{z}$ dnia 10 maja 2018 r. o ochronie danych osobowych.

Problematyczny pozostaje jednak nadal zakres danych dotyczących przekonań religijnych i przynależności wyznaniowej osób zatrudnionych w podmiotach konfesyjnych w związku z ich działalnością statutową. Inne bowiem przesłanki będą decydować o możliwości ich przetwarzania przez pracodawcę kościelnego w odniesieniu do osób będących członkami tego Kościoła, którzy podejmują w nim zatrudnienie, a inne w odniesieniu do pracowników o odmiennej przynależności religijnej czy ideologicznej. Stąd należy wysunąć jako postulat de lege ferenda stworzenie szczegółowych przepisów wewnętrznych, które w ramach ochrony danych osobowych w Kościołach i innych związkach wyznaniowych odnosiłyby się do pozyskiwania i gromadzenia w dokumentacji związanej z procesem naboru, zatrudnienia i po jego ustaniu niezbędnych danych osobowych, m.in. od osób zatrudnionych w Kościele, a nie przynależących do danej konfesji. Ważne jest też ich właściwe zabezpieczenie. Zgodnie bowiem ze stanowiskiem judykatury przetwarzanie danych osobowych polegające na ujawnianiu przekonań religijnych osób niebędących członkami danego Kościoła czy innego związku wyznaniowego, nawet gdy służy to wykonywaniu statutowych funkcji tych podmiotów, jest zabronione ${ }^{37}$.

\section{Bibliografia}

Drozd A., Ustawa o ochronie danych osobowych. Komentarz. Wzory pism i przepisy, Warszawa 2006.

Kodeks pracy. Komentarz. Wyd. 2, A. Sobczyk (red.), Warszawa 2015.

Kulesza E., Ochrona danych osobowych a wolność sumienia $i$ wyznania $w$ prawodawstwie polskim, w: P. Majer (red.), Ochrona danych osobowych i prawo do prywatności w Kościele, Kraków 2001.

Makowski D., Ochrona danych osobowych wedtug wytycznych Międzynarodowego Biura Pracy, „Inspektor Pracy” 2000, 1-2.

Mazurkiewicz P., Ochrona danych osobowych $w$ Kościołach i związkach wyznaniowych w świetle Rozporzadzenia Parlamentu Europejskiego i Rady (UE) 2016/679 z dnia 27 kwietnia 2016 r. w sprawie ochrony osób fizycznych w zwiąku z przetwarzaniem danych osobowych $i$ w sprawie swobodnego przepływu takich danych oraz uchyleniu dyrektywy 95/46 WE, w: S. Dziekoński, P. Drobek, Ochrona danych osobowych w Kościele, Warszawa 2016.

Mezglewski A., Działalność związków wyznaniowych, a ochrona danych osobowych, Studia z Prawa Wyznaniowego 2007, 10.

37 Wyrok NSA z 27 marca 2013 r., sygn. I OSK 932/12, http://orzeczenia .nsa.gov.pl/doc/847F36456C (dostęp: 14.07.2018). 
Mezglewski A., Perspektywa i zakres implementacji nowych przepisów Unii Europejskiej dotyczacych przetwarzania danych osobowych przez związki wyznaniowe, w: S. Dziekoński, P. Drobek, Ochrona danych osobowych w Kościele, Warszawa 2016.

Mielczarek M.A., Realizacja wolności religijnej w zatrudnieniu pracowniczym, Warszawa 2013.

Orzeszyna K., Podstawy relacji między państwem a Kościołami w konstytucjach państw członkowskich i traktatach Unii Europejskiej, Lublin 2007.

Poniatowski M., Przetwarzanie danych osobowych w kościelnych organizacjach pożytku publicznego, w: S. Dziekoński, P. Drobek, Ochrona danych osobowych w Kościele, Warszawa 2016.

Sobczyk P., Ograniczenie praw podmiotu ze względu na przetwarzanie danych osobowych dotyczacych przekonań religijnych i przynależności wyznaniowej, Studia z Prawa Wyznaniowego 2010, 13.

Wolnicki P., Kucharski O., Formy zatrudnienia i ich dokumentacja w kościołach i innych związkach wyznaniowych, Częstochowa 2018. 